\title{
Titanium Dioxide Nanoparticles as an Environmental Sanitizing Agent
}

\section{Sujata Sirsat $A^{*}$ and Jack Neal A}

Hilton College of Hotel and Restaurant Management, University of Houston, USA

\begin{abstract}
Environmental sanitation is crucial especially in organizations such as hotels that cater to medical tourism, daycare facilities, and nursing homes. This is because the majority of the population may be immunocompromised. The goal of this study was to investigate the efficacy of Titanium Dioxide Nanoparticles (TDN) against environmental microorganisms found on hotel room fomites (e.g. remote control, door knobs, and bathroom floors) before and after treatment with TDN with hotel room blinds open (since TDN is a photocatalyticcompund). Following this, the effect of TDN was studied on coupons (porous=carpet and non-porous=Formica) inoculated with specific pathogenic bacteria (Salmonella, Listeria, and E. coli O157:H7) and viral surrogates (MS2). These studies were carried out under dark and light conditions. The results showed a reduction in Salmonella (98.03\% and $22 \%)$, E. coli $(97.77 \%$ and $97.8 \%)$ and MS2 (23\% and 15.7\%) under both light and dark conditions respectively; although, increased reduction in bacterial CFU and viral PFU were observed under light conditions Reduction of Listeria was not observed under either dark or light conditions. This could be because of difference in membrane composition between Gram-positive and Gram-negative microorganisms. The results showed that the use of TDN for environmental sanitation is effective and could reduce the risk of infections due pathogenic microorganisms transfer via fomites.
\end{abstract}

Keywords: Titanium dioxide; Nanoparticles; Sanitation; Public health; Medical tourism

\section{Introduction}

Several studies have demonstrated the application of titanium dioxide as an antimicrobial agent. In addition, there has been an increasing interest in applying this agent to disinfect air, water, and fomites. Photoactivated titanium dioxide has been shown to be effective against Gram-negative and Gram-positive bacteria, fungi, viruses, and bacteriophage [1]. Hence, the compound has been documented to have applications in diverse arenas. For instance, titanium dioxide has been applied to catheters to prevent urinary tract infections [2,3], dental implants [4], food packaging films [5], and wood [6]. Microscopic and cell leakage studies have shown that the mode of action of titanium dioxide is targeting cell membranes leading to cell wall damage followed by cell death [7].

Previous studies have shown that environmental surfaces are likely reservoirs for pathogenic microorganisms[8-12]. In addition, studies have shown that these microorganisms can survive for extended periods of time on fomites [13]. Hand contact with contaminated surfaces and subsequent hand to mouth transfer has been identified as a potential mode of transmission for pathogenic microorganisms during outbreaks in a variety of settings including long term care facilities, cruise ships, and hotels [13-17].

Settings where people work or live in close quarters are especially vulnerable to outbreaks. The primary risk factor associated with outbreaks in enclosed settings is sharing a restroom or sleeping quarters with someone who has been sick with vomiting or diarrhea [18]. If not properly disinfected, the areas where people become sick may be contaminated creating "hot spots" of contamination [19]. Conventional cleaning and sanitizing methods such as wiping are time-intensive, staff intensive, and most importantly, cannot be standardized $[20,21]$. Hence, in addition to traditional methods using chemical disinfectants, there is an increasing need to employ "deep cleaning" methods to regularly sanitize fomites to reduce the presence of pathogens and decrease the likelihood of sickness.

The objective of this study was two-fold: 1 . Investigate the efficacy of titanium dioxide nanoparticles on environmental surfaces using a hotel room as a model to simulate hotels that cater to medical tourism; and 2. Test the effect of titanium dioxide nanoparticles specifically on porous (carpet) and non-porous (Formica) coupons inoculated with bacteriophage MS2 and bacterial pathogens.

\section{Materials and Methods}

\section{Antimicrobial sanitizing agent and sampling}

Titanium dioxide in liquid form was obtained from Natural Shield Technologies (Houston, TX) and used as the sanitizing agent The sanitizing agent was sprayed in the hotel rooms for approximately 30 min in the presence of natural light. The hotel rooms were sampled before and after administering the sanitizing agent to investigate the efficacy of the antimicrobial on environmental microorganisms. Nine surfaces in each hotel room were chosen based on previous studies $[20,21]$ and tested and these surfaces are listed in Table 1. Each sample area was swabbed aseptically in a $5 \mathrm{~cm}^{2}$ area region using sterile cotton swabs (The CITMED Corporation, Citronelle, AL) moistened in phosphate buffered saline (PBS) solution using a sterile aluminum foil template. The area was swabbed according to the sampling protocol previously described by [22]. Following this, the wooden handle of each swab was snapped off to ensure aseptic practices and the cotton portion remained in the PBS filled $15 \mathrm{ml}$ centrifuge tubes and capped. The samples were placed in insulated boxes and transported to the Food Safety Laboratory at the University of Houston. Two samples were taken from each region and the experiment was repeated twice. An average of numbers were used for data analysis.

*Corresponding author: Sujata Sirsat A, Hilton College of Hotel and Restaurant Management, University of Houston, USA, Tel: 713-743-2255; E-mail: sasirsat@central.uh.edu

Received February 19, 2015; Accepted March 18, 2015; Published March 25 2015

Citation: Sujata Sirsat A, Jack Neal A (2015) Titanium Dioxide Nanoparticles as an Environmental Sanitizing Agent. J Microb Biochem Technol 7: 061-064. doi:10.4172/1948-5948.1000183

Copyright: ( 2015 Sujata Sirsat A, et al. This is an open-access article distributed under the terms of the Creative Commons Attribution License, which permits unrestricted use, distribution, and reproduction in any medium, provided the original author and source are credited 


\begin{tabular}{|c|c|c|c|c|c|c|c|c|c|}
\hline & Carpet & $\begin{array}{c}\text { Bedside lamp } \\
\text { switch }\end{array}$ & Phone Keypad & Couch & $\begin{array}{c}\text { TV Remote } \\
\text { Keypad }\end{array}$ & $\begin{array}{c}\text { Bathroom } \\
\text { Faucet }\end{array}$ & $\begin{array}{c}\text { Bathroom } \\
\text { Sink Basin }\end{array}$ & $\begin{array}{c}\text { Toilet Flush } \\
\text { Lever }\end{array}$ & $\begin{array}{c}\text { Toilet Bowl } \\
\text { APC }\end{array}$ \\
\hline Yeast & 23.4 & 2.12 & 7.8 & 1.5 & 50.5 & 4.3 & 0.31 \\
\hline Mold & 0.25 & 0.4 & 0.33 & 4.5 & 0.75 & 1.35 & 0.25 \\
\hline
\end{tabular}

Microbial counts were conducted before and after titanium dioxide spray in hotel rooms. Microorganisms were quantified over a 4-week period

Table 1: Reduction of environmental microorganisms on nine hotel room surfaces following titanium dioxide spray after four weeks

\section{Environmental bacterial quantification}

Aerobic Plate Counts (APCs) were used to assess bacterial contamination. APCs were conducted using Petrifilm ${ }^{\mathrm{TM}}$ Aerobic Count Plates (3M Microbiology Products, St. Paul, MN) to determine the aerobic bacteria. The microbial samples were vortexed in the centrifuge tubes for ten seconds using a fixed speed vortex mixer (VWR, Radnor, PA) to release the microorganisms from the swab. One $\mathrm{ml}$ of the PBS solution from the vortexed tubes was pipetted onto the APC Petrifilm ${ }^{\mathrm{TM}}$. A plastic spreader disc was placed on top of the film to disperse solution (as per the manufacturer's instructions) and the film was incubated for $24 \mathrm{~h}$ at $37^{\circ} \mathrm{C}$ and enumerated. The samples were also plated on Petrifilm ${ }^{\mathrm{TM}}$ Escherichia colicoliform Count Plates and incubated at $35^{\circ} \mathrm{C}$ for 24 hours and enumerated. Similarly, Yeast and Mold Count Petrifilm ${ }^{\mathrm{TM}}$ was used for environmental allergen quantification.

\section{Pathogenic bacterial strains and viral surrogates}

The following pathogenic bacteria were used in this study: Salmonella Muenchen (BAA-1594), Salmonella Thompson (BAA1604), Salmonella Typhimurium (ATCC 14028), two Listeria monocytogenesstrains (ATCC 51414 and ATCC 43256), and E. coli O157:H7 (ATCC 43895). All strains were obtained from American Type Culture Collection (ATCC) and stored at $-80^{\circ} \mathrm{C}$ in glycerol. Coliphage MS2 and its host E. coli B-15597 were obtained from ATCC (Manassas, VA). The MS2 coliphage was propogated using $E$. coliB-15597 as host in Tryptic Soy Broth (TSB; EMD, Bellerica, MA) as per ATCC's guidance documents. Briefly, E. coli B-15597 was grown overnight in TSB broth at $37^{\circ} \mathrm{C}$. The overnight culture $(100 \mu \mathrm{l})$ was added to $100 \mathrm{ml}$ of fresh TSB broth and grown until mid-log phase determined by spectrophotometric analysis. The TSA soft agar was placed in a $50^{\circ} \mathrm{C}$ water bath until needed for the experiment. The phage was rehydrated with $1 \mathrm{ml}$ TSB and appropriate serial dilutions were performed. The mid-log phase E. coli cells B-15597 (75 $\mu \mathrm{l})$ and $1 \mathrm{ml}$ phage were added to $5 \mathrm{ml}$ of pre-warmed TSA soft agar in a borosilicate tube. The tube was mixed gently and poured on TSA plates. The agar was allowed to solidify before placing the plates in a $37^{\circ} \mathrm{C}$ incubator overnight. The top agar layer was scraped with a sterile cell scraper and placed in a $15 \mathrm{ml}$ polypropylene tube containing $1 \mathrm{ml}$ peptone and 6 $\mathrm{ml}$ chloroform. The tube was vortexed for $5 \mathrm{~min}$ and centrifuged at $4000 \mathrm{~g}$ for $30 \mathrm{~min}$. The supernatant was removed and filtered through a $0.22 \mu \mathrm{M}$ filter. The phage particles were quantified and appropriate dilutions were inoculated on environmental coupons. The phage stocks were stored at $-80^{\circ} \mathrm{C}$.

\section{Bacterial and viral inoculation on coupons}

The coupons were inoculated with bacteria as described previously by [23]. Briefly, coupons from various environmental samples (Formica, carpet and light switch) were designed in $5 \mathrm{~cm} \mathrm{x} 5 \mathrm{~cm}$ dimensions. The coupons were cleaned, dried, wrapped in aluminum foil and sterilized in an autoclave at $12^{\circ} \mathrm{C}$ for $15 \mathrm{~min}$. The sterilized coupons were stored at room temperature before the experiment. Six pathogenic bacterial strains were grown individually in Tryptic
Soy Broth (Sigma-Aldrich, St Louis, MO) overnight. Following this, $0.5 \mathrm{ml}$ of each strain was added to $0.1 \%$ peptone buffer yielding a final volume of $50 \mathrm{ml}$. The coupons were placed in a sterile petri dish and $0.5 \mathrm{ml}$ of the pathogen cocktail was pipetted and spread with a sterile spreader. The coupons were allowed to dry for $10 \mathrm{~min}$ and the $0 \mathrm{~h}$ sample was processed immediately. The coupon was placed in a sterile stomacher bag with $90 \mathrm{ml} 0.1 \%$ peptone and stomached for $120 \mathrm{sec}$. Serial dilutions were performed in $0.1 \%$ peptone water and samples were spread plated on Eosin methylene blue (EMB) agar (EMB HiVeg ${ }^{\mathrm{TM}}$ Agar, Levine, HiMedia Laboratories Pvt. Ltd. India) to identify E. coli and Salmonellacolonies and PALCAM Listeria Agar Base with PALCAM Listeria Selective Supplement (EMD Chemicals Inc., Germany) to identify Listeria colonies. The plates were incubated at $37^{\circ} \mathrm{C}$ for $48 \mathrm{~h}$ and then colonies were quantified using the viable cell count method. For bacteriophage analysis, appropriate dilutions of phage were inoculated on the sterile coupons and processed in the same manner as described above. The phage PFU's were quantified by the double agar layer method as described by [24] and the plaque forming units were quantified.

\section{Statistical analysis}

Statistics were performed using SPSS 22 for Macintosh to analyze standard deviations and perform t-tests analyses. Paired t-test analysis was performed to identify significant differences between bacterial viability and bacteriophage presence before and after antimicrobial treatment.

\section{Results and Discussion}

Studies by $[20,21]$ showed that cleaning protocols are not standardized across or within hotel brands. This shows an increasing need to address good practices for disinfection especially in light of a crisis. These practices are even more crucial for hotels that cater to medical tourism (where people travel to another city or country for medical treatment and may live in a hotel for an extended period of time), nursing homes, and day care facilities where majority of the population is immunocompromised.

The results of this study showed that the titanium dioxide nanoparticles were effective at reducing microbial counts in the hotel room environment over 4 -weeks. The goal of this study is to propose the use of titanium dioxide as a "deep cleaning" method that can be performed once every month to mimic standard deep cleaning protocols in the hotel industry. Hence, the analysis was conducted over four weeks to test the efficacy of this sanitizing method. As seen in table 1, APC counts on the carpet and TV remote control decreased by 23.4 and $50.5 \mathrm{CFU} / \mathrm{cm}^{2}$ respectively over four weeks. Overall, low yeast and mold counts were observed on various fomites in the hotel room hence the counts decreased only up to $1.25 \mathrm{CFU} / \mathrm{cm}^{2}$ over 4 -weeks. These are positive results since yeast and mold have been shown to be allergens among some individuals [25]. Tables 2 and 3 demonstrate the efficacy of titanium dioxide nanoparticles on carpet coupons (porous surface) inoculated with bacterial pathogens in light and dark conditions respectively since titanium dioxide is photocatalytic. The 


\begin{tabular}{|c|c|c|c|}
\hline Time & Salmonella Typhimurium & Escherichia coli O157:H7 & Listeria monocytogenes \\
\hline Day 0 & $1.0 \pm 0.15^{\mathrm{a}}$ & $0.6 \pm 0.1^{\mathrm{a}}$ \\
\hline Day 1 & $3.5 \pm 0.3^{\mathrm{a}}$ & $6.2 \pm 0.1^{\mathrm{b}}$ & $5.0^{\mathrm{a}} \pm 0.1^{\mathrm{a}}$ \\
\hline Day 2 & $6.3 \pm 0.1^{\mathrm{c}}$ & $6.1 \pm 0.01^{\mathrm{b}}$ & $5.5 \pm 0.1^{\mathrm{a}}$ \\
\hline
\end{tabular}

conditions after exposure to the sanitizing agent.

Carpet coupons inoculated with 3 different pathogenic bacteria were treated with titanium dioxide and incubated in the presence of light. Viability analyses were conducted over 2-days.

Table 2: Log reduction of pathogenic bacteria on carpet coupons incubated in light.

\begin{tabular}{|c|c|c|c|}
\hline Time & Salmonella Typhimurium & Escherichia coli O157:H7 & Listeria monocytogenes \\
\hline Day 0 & $1.8 \pm 0.17^{\mathrm{a}}$ & $0.9 \pm 0.2^{\mathrm{a}}$ & $5.1 \pm 0.09^{\mathrm{b}}$ \\
\hline Day 1 & $2.6 \pm 0.03^{\mathrm{b}}$ & $5.08^{\mathrm{a}}$ & $4.05^{\mathrm{a}}$ \\
\hline Day 2 & $3.7 \pm 0.27^{\mathrm{b}}$ & $4.0 \pm 0.3^{\mathrm{b}}$ & $5.8 \pm 0.01^{\mathrm{a}}$ \\
\hline
\end{tabular}

Carpet coupons inoculated with 3 different pathogenic bacteria were treated with titanium dioxide and incubated in the absence of light. Viability analyses were conducted over 2-days.

Table 3: Log reduction of pathogenic bacteria on carpet coupons incubated in dark conditions after exposure to the sanitizing agent.

\begin{tabular}{|c|c|c|}
\hline Time & $\begin{array}{c}\text { Bacteriophage Reduction on non-porous (formica) } \\
\text { surfaces }\end{array}$ & $\begin{array}{c}\text { Bacteriophage Reduction on porous surfaces } \\
\text { (carpet) }\end{array}$ \\
\hline Day 0 & $4.25^{\mathrm{a}}$ & $1.76^{\mathrm{a}}$ \\
\hline Day 1 & $3.5^{\mathrm{b}}$ & $1.25^{\mathrm{a}}$ \\
\hline Day 2 & $3^{\mathrm{b}}$ & $3^{\mathrm{b}}$ \\
\hline
\end{tabular}

Porous (carpet) and non-porous (Formica) coupons inoculated with MS2 bacteriophage were treated with titanium dioxide and incubated in the presence of light. Viability analyses were conducted over 2-days.

Table 4: Phage forming unit reduction in MS2 bacteriophage incubated on porous and non-porous surfaces after exposure to sanitizing agent.

results indicate that coupons exposed to light showed a slightly better reduction of bacterial pathogens compared to coupons exposed to dark conditions. For instance, Salmonella Typhimurium reduced to $6.3 \mathrm{log}$ $\mathrm{CFU} / \mathrm{cm}^{2}$ when exposed to light versus $3.7 \log \mathrm{CFU} / \mathrm{cm}^{2}$ when exposed to dark conditions after 2 days. Similarly, E. coli O157:H7 reduced 6.1 $\log \mathrm{CFU} / \mathrm{cm}^{2}$ and $4 \log \mathrm{CFU} / \mathrm{cm}^{2}$ after 2 days when exposed to light and dark conditions respectively. No viable Salmonella or E. coli colonies were observed at the end of day 2 in the test coupons. Neither light nor dark conditions in combination with titanium dioxide had any effect on the viability of Listeria monocytogenes. The difference in cell viability between Gram-positive and Gram-negative bacteria could be caused by membrane differences. Gram-negative bacteria have a triplelayer cell wall with an inner membrane, a thin peptidoglycan layer and an outer membrane. Conversely, Gram-positive bacteria have a thicker peptidoglycan layer and no outer membrane [26].

Similar experiments were conducted on non-porous surfaces such as Formica and the results showed a complete reduction of pathogens in light and dark conditions (data not shown). Table 4 shows the efficacy of the titanium dioxide nanoparticles against bacteriophage MS2 on non-porous (Formica) and porous (carpet) coupons in light conditions. No reduction of PFUs was seen in dark conditions (data not shown). As seen in the data table, bacteriophage counts reduced on both non-porous and porous surfaces by $3 \log \mathrm{CFU} / \mathrm{cm}^{2}$ at day 2 . MS2 is often used as a surrogate to represent the "worst case scenario" due to its viability and relative increased resistance to disinfection [27].

Independent studies have shown that the persistence of microorganisms in the environment is dependent on several factors such as temperature, moisture levels, fomite properties, and microbe type [28]. Bacteria are more likely to be found in high numbers on porous surfaces and under moist conditions [28]. Also, studies show that transfer rate of microorganisms from non-porous surfaces to hands and vice-versa is more efficient since the microorganisms are not absorbed by these surfaces $[23,29]$. Transfer rates from porous surfaces ranged from $28 \%$ to $65 \%$ and non-porous surfaces was $<0.01 \%[28,30]$ tested for the presence of bacteria, norovirus, and influenza A virus on fomites in elementary classrooms. Their results showed that high-touch areas such as water fountain toggles, pencil sharpeners, key boards, and faucets had high bacterial loads. Desktops, faucet handles, and paper towel dispensers were often contaminated with viruses. Similarly, [31] showed that norovirus was often transmitted to high touch areas such as taps, door handles, and telephone receiver by contaminated hands. Moreover, the study demonstrated that contaminated hands could transfer the virus to up to seven clean surfaces. The investigators also performed a comparative analysis of hypochlorite/detergents and chlorine based cleaners against norovirus. While chlorine based compounds were more effective at reducing norovirus rates, the virus was still found on $28 \%$ of the surfaces. [28] demonstrated that bacteria (Gram-positive and Gram-negative) and phage transferred more efficiently from hard, non-porous surfaces to hands at up to $10^{6}$ cells or phage forming units. These results show that there is an increasing need to identify an effective cleaning practice to prevent illness caused due to environmental contamination.

A 2011 norovirus outbreak was traced to a reusable cloth grocery bag that had been stored in the bathroom [32]. Airborne contamination of fomites is a huge concern with bacterial and viral pathogens and has been a cause of outbreaks. Once a fomite is contaminated, transfer to hands and other animate or inanimate objects can occur readily [33]. There has been limited evaluation of the role of fomites in disease transmission. For instance, the route of transmission in multiple nosocomial infections is not documented and fomites are not tested [34]. Effective cleaning methods are crucial especially in the event of an illness episode. During the summer of 2005 a norovirus outbreak occurred in a residential college summer camp. Interestingly, the number of norovirus positive rooms increased after the first room cleaning from $40 \%$ to $73 \%$ [35]. This shows that appropriate cleaning is crucial for disinfection after an illness in any environment to prevent the spread of infection.

Several studies have demonstrated the efficacy of titanium 
Citation: Sujata Sirsat A, Jack Neal A (2015) Titanium Dioxide Nanoparticles as an Environmental Sanitizing Agent. J Microb Biochem Technol 7: 061-064. doi:10.4172/1948-5948.1000183

dioxide especially in combination with UV or light. For instance, [36] demonstrated that titanium dioxide in combination with UV showed a significant decrease in Salmonella, Vibrio, and Listeria cell viability after $30 \mathrm{~min}$. [37] showed that E. coli, P. aeruginosa, and S. aureuswere reduced by approximately 6 logs in $60 \mathrm{~min}$ after treatment with photo catalytic titanium dioxide. However, all these studies showed increased efficacy of titanium dioxide as an antimicrobial agent in the presence of UV or light. The results of the current study show similar trends; however, the hotel room component of the study was performed in the presence of natural light (blinds or curtains in the hotel room were opened) when the antimicrobial was sprayed.

\section{Conclusion}

This study highlights the need for effective and standardized cleaning and sanitizing methods in environments most commonly occupied by immunocompromised individuals. These environments may include day care centers, nursing homes, and hotels that cater to medical tourism. The titanium dioxide treatment may also be applied to closed quarters such as cruise ships and military vessels where the risk of airborne contamination increases in the event of an individual becoming ill.

\section{References}

1. Paspaltsis I, Kotta K, Lagoudaki R, Grigoriadis N, Poulios I, et al. (2006) Titanium dioxide photocatalytic inactivation of prions. J Gen Virol 87: 31253130.

2. Yao Y, Ohko Y, Sekiguchi Y, Fujishima A, Kubota Y (2008) Self-sterilization using silicone catheters coated with $\mathrm{Ag}$ and $\mathrm{TiO} 2$ nanocomposite thin film. $J$ Biomed Mater Res B Appl Biomater 85: 453-460.

3. Ohko Y, Utsumi Y, Niwa C, Tatsuma T, Kobayakawa K, et al. (2001) Selfsterilizing and self-cleaning of silicone catheters coated with $\mathrm{TiO}(2)$ photocatalyst thin films: a preclinical work. J Biomed Mater Res 58: 97-101.

4. Mo AC, Xu W, Qin Xian S, Li YB, Bai S (2007) Antibacterial activity of silverhydroxyapatite/titania nanocomposite coating on titanium against oral bacteria. Key Engineering Materials 330: 455-458.

5. Chawengkijwanich C, Hayata Y (2008) Development of TiO2 powder-coated food packaging film and its ability to inactivate Escherichia coli in vitro and in actual tests. Int J Food Microbiol 123: 288-292.

6. Chen J, Chi-Sun P (2009) Photocatalytic construction and building materials: from fundamentals to applications. Building and Environment 44: 1899-1906.

7. Saito T, Iwase T, Horie J, Morioka T (1992) Mode of photocatalytic bactericidal action of powdered semiconductor TiO2 on mutans streptococci. J Photochem Photobiol B 14: 369-379.

8. Talon D (1999) The role of the hospital environment in the epidemiology of multi-resistant bacteria. J Hosp Infect 43: 13-17.

9. Kim KH, Fekety R, Batts DH, Brown D, Cudmore M, et al. (1981) Isolation of Clostridium difficile from the environment and contacts of patients with antibiotic-associated colitis. J Infect Dis 143: 42-50

10. Evans MR, Meldrum R, Lane W, Gardner D, Ribeiro CD, et al. (2002) An outbreak of viral gastroenteritis following environmental contamination at a concert hall. Epidemiol Infect 129: 355-360.

11. Dancer SJ (2009) The role of environmental cleaning in the control of hospitalacquired infection. J Hosp Infect 73: 378-385.

12. Gallimore Cl, Taylor C, Gennery AR, Cant AJ, Galloway A, et al. (2006) Environmental monitoring for gastroenteric viruses in a pediatric primary immunodeficiency unit. J Clin Microbiol 44: 395-399.

13. Cheesbrough JS, Green J, Gallimore CI, Wright PA, Brown D.W (2000) Widespread environmental contamination with norwalk-like viruses (NLV) detected in a prolonged hotel outbreak of gastroenteritis. Epidemiology and Infection 125: 93-98.

14. Kuusi M, Nuorti JP, Maunula L, Minh Tran NN, Ratia M, et al. (2002) A prolonged outbreak of Norwalk-like calicivirus (NLV) gastroenteritis in a rehabilitation centre due to environmental contamination. Epidemiol Infect 129: 133-138.
15. Wu H M, Fornek M, Schwab E, Schwab KJ, Chapin AR (2005) A norovirus outbreak at a long-term-care facility: The role of environmental surface contamination. Infection Control and Hospital Epidemiology 26: 802-810.

16. Kimura H, Nagano K, Kimura N, Shimizu M, Ueno Y, et al. (2011) A norovirus outbreak associated with environmental contamination at a hotel. Epidemiol Infect 139: 317-325.

17. Love SS, Jiang X, Barrett E, Farkas T, Kelly S (2002) A large hotel outbreak of Norwalk-like virus gastroenteritis among three groups of guests and hotel employees in Virginia. Epidemiol Infect 129: 127-132.

18. Ho MS, Glass RI, Monroe SS, Madore HP, Stine S, et al. (1989) Viral gastroenteritis aboard a cruise ship. Lancet 2: 961-965.

19. Riddle MS, Sanders JW, Putnam SD, Tribble DR (2006) Incidence, etiology and impact of diarrhea among long-term travelers (US military and similar populations): a systematic review. Am J Trop Med Hyg 74: 891-900.

20. Almanza B, Kirsch K, Kline S, Sirsat SA, Stroia O, et al. (2015a) How clean are hotel rooms: Visual observations versus microbiological contamination. Journal of Environmental Health. In print.

21. Almanza B, Kirsch K, Kline S, Sirsat SA, Stroia O, et al., (2015b) Examining the concept of cleanliness standards in hotel rooms. Journal of Environmental Health. In print.

22. Davidson CA, Griffith CJ, Peters AC, Fielding LM (1999) Evaluation of two methods for monitoring surface cleanliness-ATP bioluminescence and traditional hygiene swabbing. Luminescence 14: 33-38.

23. Sirsat SA, Choi JK, Almanza BA, Neal JA (2013) Persistence of Salmonella and $E$. coli on the surface of restaurant menus. J Environ Health 75: 8-14.

24. Bae J, Schwab KJ (2008) Evaluation of murine norovirus, feline calicivirus poliovirus, and MS2 as surrogates for human norovirus in a model of viral persistence in surface water and groundwater. Applied and Environmental Microbiology 74: 477-484.

25. Behbod B, Sordillo JE, Hoffman EB, Datta S, Muilenberg ML, et al. (2013) Wheeze in infancy: protection associated with yeasts in house dust contrasts with increased risk associated with yeasts in indoor air and other fungal taxa. Allergy 68: 1410-1418.

26. Foster HA, Ditta IB, Varghese S, Steele A (2011) Photocatalytic disinfection using titanium dioxide: spectrum and mechanism of antimicrobial activity. App Microbiol Biotechnol 90: 1847-1868.

27. Fisher $E$, Shaffer R (2010) Survival of bacteriophage MS2 on filtering facepiece respirator coupons. Applied Biosafety 15: 71-85.

28. Rusin P, Maxwell S, Gerba C (2002) Comparative surface-to-hand and fingertip-to-mouth transfer efficiency of gram-positive bacteria, gram-negative bacteria, and phage. J Appl Microbiol 93: 585-592.

29. Rheinbaben F V , Schünemann S, Gross T, Wolff MH (2000) Transmission of viruses via contact in a household setting: experiments using bacteriophage fX174 as a model virus. Journal of Hospital Infection 46: 61-66.

30. Bright KR, Boone SA, Gerba CP (2010) Occurrence of bacteria and viruses on elementary classroom surfaces and the potential role of classroom hygiene in the spread of infectious diseases. J Sch Nurs 26: 33-41.

31. Barker J, Vipond IB, Bloomfield SF (2004) Effects of cleaning and disinfection in reducing the spread of Norovirus contamination via environmental surfaces. J Hosp Infect 58: 42-49.

32. Repp KK, Keene WE (2012) A point-source norovirus outbreak caused by exposure to fomites. J Infect Dis 205: 1639-1641.

33. Boone SA, Gerba CP (2007) Significance of fomites in the spread of respiratory and enteric viral disease. Appl Environ Microbiol 73: 1687-1696.

34. Cone R, Mohan K, Thouless M, Corey L (1988) Nosocomial transmission of rotavirus infection. Pediatr Infect Dis J 7: 103-109.

35. Fankem SL, Boone SA, Gaither M, Gerba CP (2014) Outbreak of norovirus illness in a college summer camp: impact of cleaning on occurrence of norovirus on fomites. J Environ Health 76: 20-26.

36. Kim B, Kim D, Cho D, Cho S (2003) Bactericidal effect of TiO2 photocatalyst on selected food-borne pathogenic bacteria. Chemosphere 52: 277-281.

37. Kühn KP, Chaberny IF, Massholder K, Stickler M, Benz VW, et al. (2003) Disinfection of surfaces by photocatalytic oxidation with titanium dioxide and UVA light. Chemosphere 53: 71-77. 